A AESBM

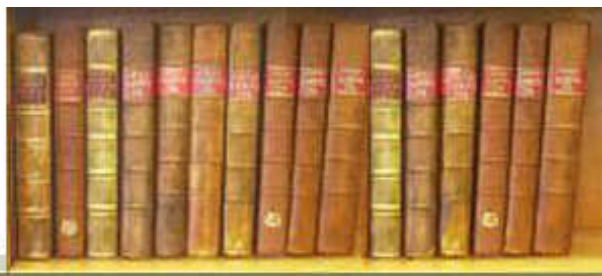

\title{
Socio-demographic analysis of festival entrepreneurs in South Africa
}

\author{
Jonker, E. and Saayman, M. \\ Institute for Tourism and Leisure Studies, \\ North-West University, Potchefstroom campus, Private Bag X6001, 2520 \\ South Africa \\ Melville.Saayman@nwu.ac.za
}

\begin{abstract}
The purpose of this article is to examine the socio-demographic differences between entrepreneurs at National Arts festivals in South Africa. Language, and specifically Afrikaans, English and African languages, was used as the dependent variable. The Klein Karoo National Arts Festival (KKNK) in Oudtshoorn and the Grahamstown National Arts Festival (GNAF) are the two largest arts festivals in South Africa. The research was conducted by means of a questionnaire survey $(\mathrm{N}=500)$. The data from KKNK and GNAF were combined and factor analyses were applied to determine the role and attributes of entrepreneurs. Cross-tabulation analyses were used to illustrate the comparison of language with socio-demographical variables (marital status, qualification, province, family business, personal attributes, business premises and resourcefulness) and the role and attributes of entrepreneurs. In addition, the association of language with independent variables was examined by means of one-way ANOVA for the three language groups. Findings suggest that there are significant differences in festival entrepreneurs from different cultures (languages), especially in terms of socio-demographic variables such as marital status, education, province, business and personal attributes (resourcefulness).
\end{abstract}

Keywords and phrases: Klein Karoo National Arts Festival, Grahamstown National Arts Festival, festival entrepreneur, factor analysis, cross-tabulation analysis, ANOVA, entrepreneurs, language 


\section{INTRODUCTION}

Festivals, as stated by Allen, O'Toole, Harris and McDonnell (2008:15), contribute a great deal to the social and cultural life of a community, and are an important expression of human activity. Festivals are also increasingly linked with tourism to generate business activity and income for the host communities. An arts festival, according to Allen et al. (2008:15), is the most common type of festival, which can include mixed art forms at multiple venues. These festivals can be defined as celebrations of a community - to serve as a public demonstration of what the community is all about (Allen et al., 2008:15). Arts festivals often include various types of fine arts together with other cultural expressions to make them more broadly appealing (Jackson \& O'Sullivan, 2002:327).

According to Getz (2007:403), and Saayman, Douglas and De Klerk (2009), festivals are a category of events and they play an important role in the development of tourist attractions in terms of community-building, urban renewal and entrepreneurial growth. Whitford (2004a, 2004b:81) concluded that little recognition has been given to events which include festivals in terms of the facilitation of entrepreneurial enterprises and regional development, and suggested that a proactive entrepreneurial approach to the development of government policy on events is needed. It is thus important that more research is done in order to obtain a better understanding of entrepreneurial activity at events. Hence this research, which was conducted at the two largest arts festivals in South Africa, namely the Klein Karoo National Arts Festival (hereafter referred to as KKNK) and the Grahamstown National Arts Festival (hereafter referred to as GNAF).

The KKNK was established in 1994 as a way to preserve the Afrikaans language, and has since developed into the largest arts festival in South Africa (Kitshoff, 2004a: 238; Slabbert, Saayman, Saayman \& Viviers, 2007a:41). The KKNK is held annually in the town of Oudtshoorn and the festival has an estimated economic impact of R71 million. The GNAF is the oldest national arts festival in South Africa and was established in 1974 with the purpose of providing a cultural experience for the tourists and visitors and to grow the local economy (Kitshoff, 2004b:246). The economic impact of the GNAF was estimated at R51 million in 2007 (Slabbert et al., $2007 \mathrm{~b}: 41)$. The purpose of this article is to analyse the socio-demographic differences of festival entrepreneurs at these two festivals. In order to achieve the goal of the article, it is structured as a literature review that follows the introduction. Thereafter the method of research will be explained, followed by the results, findings, implications and conclusions. 


\section{LITERATURE REVIEW}

Research indicates that entrepreneurial activity leads to economic growth (Audretsch \& Thurik, 2001; Carree \& Thurik, 2003; Van Stel, Carree \& Thurik, 2005; Ulign \& Brown, 2004:22). Since 1994, the South African government has been committed to developing entrepreneurship through its strategies and has put a large number of resources, financial support, and policies into the development of entrepreneurial ventures (Ahwireng-Obeng, 2005:15). This has been done specifically to increase the number of black entrepreneurs. Strategies included establishing institutions such as development corporations as well as incentive schemes to support entrepreneurs in the different provinces. According to Ligthelm (2006:48), the needs in the South African economy can largely be addressed by promoting entrepreneurship and establishing education as the foundation where people are introduced to an entrepreneurial culture.

Entrepreneurship is a process that explores opportunities that either exist in the environment, or are produced through innovation in order to create value (Ulign \& Brown, 2004:5-7). Entrepreneurs can be defined as people who perceive opportunities and combine production factors in creative and innovative ways to develop their initial idea into profitable businesses (Bolton \&Thompson, 2004:16; Gartner, 1990:27; Duening \& Sherrill, 2007:31; Timmons \& Spinelli, 2004:47). However, Jonker, Saayman and De Klerk (2009) concluded in their research that a festival entrepreneur is someone who started and manages his/her own business, and travels from festival to festival in order to promote, offer or sell his/her product or services as well as creating or adding new products.

The importance of the entrepreneur within the community where she/he operates plays a big role in the factors that drive entrepreneurs (Aggestam, 2007:31). Hence it raises the question of to what extent opportunities are created for potential entrepreneurs? Adding to the latter, Co (2003:35) states that differences in entrepreneurship among societies are believed to account for their differential rates of growth and development. Therefore it is not only economic growth that counts but also the level to which entrepreneurship is developed.

According to Amoateng and Richter (2007:11), South Africa is a multiracial, multilingual, multi-ethnic society and, because of the political history of apartheid (pre1994), the population groups have had different levels of access to the resources of the country. Entrepreneurship in a community depends on opportunities provided by the environment and the abilities and preferences of the population (Hofstede, Noorderhaven, Thurik, Uhlaner, Wennekers \& Wildeman; 2004:165). Added to this, differences in culture and socio-economic resources, such as education and income, 
have affected entrepreneurial ability and participation (Strydom, 2003:19). According to Bygrave and Minniti (2000:34), many individuals make entrepreneurial choices because of the level of entrepreneurship activity within a community. In other words, how visible is entrepreneurial development, which includes accessibility of funding, information and support.

South African cultures were generally distinguished in terms of language and race because of legislation. Concerning the latter The Population Registration Act No 30 of 1950 required that each inhabitant of South Africa be classified and registered in accordance with their racial characteristics as part of the system of apartheid. After the 1994 democratic elections all legislation that advanced the cause of segregation has been scrapped. However, the country has many different linguistic groups, with isiZulu (23.8\%), isiXhosa (17.6\%), Afrikaans (13.3\%), Sepedi (9.4\%) and English (8.2\%) being the main languages. According to Hayton, George and Zahra (2002:6), De Haas (1990:18), and Adam and Moodley (1993), the different population groups and cultures that exist within a nation, influence entrepreneurship in terms of decision-making, management, finance and positioning.

Black South Africans, according to Berger (1991:8) and Godsell (1991), are lacking in entrepreneurial history because of the political policy under apartheid rule, and are seen as isolated individuals, impeded by the lack of an entrepreneurial culture and a restrictive socio-political history. Similar to the black South African community, the Afrikaans entrepreneurs also lack entrepreneurial history and have a tendency to act alone without the mediating structure of a community (Godsell, 1991). This is because the pre-1994 government lacked policy and strategies to promote and develop entrepreneurs. English-speaking South Africans have a more established entrepreneurial history as traders, company owners, mine owners and industrialists. English is also the language most spoken in the business and educational environments in South Africa (Muller, 1980; Mesthrie, 2008:333). With entrepreneurial activity stimulating economic growth, it has become important for all those who are involved in the field of entrepreneurship to obtain a greater understanding of entrepreneurs and the aspects driving them (Bhola, Verheul, Thurik \& Grilo, 2006:29). The latter would therefore also apply in the case of festival entrepreneurs. The question under investigation is whether there are differences between festival entrepreneurs (for example Afrikaans, English and African entrepreneurs) and if so, what are these differences?

Various researchers have used socio-demographic variables to differentiate between entrepreneurs (see Appendix, Table 1). Socio-demographic variables can be defined in terms of social class and demographics. Social class refers to the 
standing of an individual in the social hierarchy, while demographics is the study of the structure of the human population (Pissoort \& Saayman, 2007:257).

Comparing the results of the socio-demographic studies indicated in Table 1, it is apparent that language, gender, age and education are the most common variables that differentiate entrepreneurs. None of these studies were conducted at a festival. This type of research is important because entrepreneurs are seen as important roleplayers in the success and future of national arts festivals (Saayman, Douglas \& De Klerk; 2009).

\section{METHOD}

Exploratory research was conducted by means of two surveys. The first survey took place during the KKNK held in Oudtshoorn from 21 to 29 March 2008, while the second survey took place at the GNAF from 26 June to 5 July 2008. The questionnaire enquired after the entrepreneurs' demographic background attributes as well as their role at the two festivals. The method of research will subsequently be examined under (a) questionnaire, (b) samples, and (c) statistical analysis.

\section{Questionnaire}

The questionnaire was developed to examine the profile of the entrepreneurs as well as their attributes and role at arts festivals in South Africa. The questionnaire used in this research was adapted from a study done by Saayman et al. (2009). It was distributed by fieldworkers to the stall owners at the KKNK and GNAF. The questionnaire had three sections, which consisted of $(A)$ demographic information, (B) business information, and (C) festival information. A Likert scale that ranged from 1 (not at all important) to 5 (extremely important) was used to determine the attributes of entrepreneurs (Tustin, Lighthelm, Martins \& Van Wyk, 2005:407) as well as their role at South African arts festivals. Open and closed questions were included that measured the socio-demographic background of entrepreneurs.

\section{Sample}

There were 511 stall owners (440 art stalls and 71 food stalls) at the KKNK and 267 stall owners (243 art stalls and 24 food stalls) at the GNAF, which totals 778 stalls. Stalls that were managed for charity purposes or where the owner was not available, 
or willing, to participate, were omitted from the survey. Therefore, availability sampling was applied in this research. Of the 600 questionnaires that were handed out at both festivals, 500 (249 at KKNK and 251 at GNAF) were completed and used in the analyses.

\section{Statistical analysis}

Microsoft Excel was used for data capturing. The data for the two festivals were combined $(\mathrm{N}=500)$ and the main difference between festival entrepreneurs at the KKNK and the GNAF is the language spoken. The KKNK is mainly an Afrikaansspeaking festival, while the GNAF caters more for English and African entrepreneurs. In total, $43 \%$ of festival entrepreneurs were Afrikaans-speaking, 35\% English-speaking and $22 \%$ spoke African languages. The African languages consisted of isiXhosa, Xitsonga and isiZulu. Because there were fewer black festival entrepreneurs at these two national art festivals than their white counterparts, it was decided to combine all black African languages. Multivariate statistics were used to examine whether there were statistically significant differences between the language groups of entrepreneurs, with language being the dependant variable. Two-way frequency tables and Chi-square tests were employed to profile the groups demographically, while one-way Analysis-of-Variance (ANOVA), cross-tabulation analysis and Tukey post-hoc tests were used to analyse differences and relationships between the language groups. The study employed the following socio-demographic variables: age, marital status, qualification, province, resourcefulness, family business, business premises, previous festivals attended and amount of shares in business, to examine whether statistically significant differences existed among different language groups.

Exploratory factor analyses and reliability tests were performed on the data to validate the constructs by means of the Statistical Package for the Social Sciences (SPSS) predictive analytics software (SPSS Inc., 2007).

The first factor analysis (pattern matrix) identified five attributes (see Appendix, Table 2 ), namely acquired skills (Cronbach alpha 0.85 ), resourcefulness $(0.83)$, selfedification (0.81), explorative (0.61) and self-efficacy $(0.71)$.

The Kaiser-Meyer-Olkin measure was 0.933 and the Bartlett test was found to be significant $(p<.0001)$. 
The second factor analysis identified three primary roles (see Appendix, Table 3 below) of festival entrepreneurs, namely festival promotion (Cronbach Alpha 0.85), product promotion (0.84) and income generation (0.70).

The Kaiser-Meyer-Olkin measure was 0.844 , which is acceptable, and the Bartlett test was also found to be significant $(p<.0001)$. One-way ANOVA as well as Tukey post-hoc tests were conducted to examine the different values that each language group attaches to the entrepreneurial attributes and its role at festivals.

\section{RESULTS}

The results will be discussed in two sections, namely the results from the crosstabulation analysis and thereafter the results from the ANOVA and Tukey's comparison.

\section{Results from the cross-tabulation analysis}

Table 4 (see Appendix) shows the comparison of language with socio-demographic variables, i.e. marital status, qualification, province, resourcefulness, family business and business premises. The association of language with socio-demographic variables was determined by means of cross-tabulation. The $x^{2}$-test statistics returned significant findings at the $5 \%$ level of significance.

The cross-tabulation comparison (see Appendix, Table 4) shows that the majority $(71.5 \%)$ of Afrikaans-speaking festival entrepreneurs were married, compared to only $57.5 \%$ of English-speaking and $42.6 \%$ of African entrepreneurs. Afrikaans- and English-speaking entrepreneurs' level of education is considerably higher than the African-language entrepreneurs' level of education. The African entrepreneurs have the highest proportion of businesses that are run from road stalls and festivals, while the English-speaking entrepreneurs have the highest proportion of formal premises (30.9\%). The Afrikaans and English groups are mainly from the Western Cape Province, whereas the African group is mainly from the Eastern Cape Province.

\section{Results from the ANOVA and Tukey's comparison}

The association of language with independent variables was examined by means of one-way ANOVA for the three language groups (see Appendix, Table 5). Significant differences were analysed with Tukey's post-hoc comparisons (Appendix, Table 5). 
The one-way ANOVA and Tukey post-hoc tests suggest that there are significant differences between the language groups (see Appendix, Table 5). Afrikaans- and English-speaking entrepreneurs at South African arts festivals are older, they attended more festivals, and they have more shares than the African entrepreneurs do. The Afrikaans and English entrepreneurs started their businesses in 1997 to 1998, while the African entrepreneurs started their businesses in 2000 to 2001.

The one-way ANOVA compared the language groups across their perceived entrepreneurial attributes. The results show a significant difference between the levels of agreement between language groups about the importance of resourcefulness as an attribute of entrepreneurs as measured on a five-point Likert scale. According to the Tukey post-hoc test (Appendix, Table 5), the Afrikaans- and English groups agreed (including attributes such as innovation, dedication and vision, to name but a few) on the importance of resourcefulness as an entrepreneurial attribute, although the African group finds it less important. The rest of the attributes, including acquired skills, self-edification, explorative and selfefficacy, factors were considered equally important across the language groups. The second factor analysis identified the role of entrepreneurs at festivals and revealed three primary roles, namely festival promotion, product promotion and income generation, of which product promotion had the highest mean value of 4.40 . No significant differences were found between language groups regarding their role at arts festivals.

\section{RELATIONSHIP BETWEEN FINDINGS AND LITERATURE}

The findings were:

- $\quad 71.5 \%$ of Afrikaans-speaking entrepreneurs were married, compared to only 57.5\% English and 42.6\% African entrepreneurs (see Appendix, Table 4). This supports research done by Kalule-Sabiti, Palamuleni, Makiwane and Amoateng (2007:109), who found that the low marriage rates among the majority African population groups can be due to the increasing popularity of non-marital cohabitation and the gradual but steady increase in the divorce rate.

- $\quad$ That the African group has a lower level of education (see Appendix, Table 4) supports the notion that inferior education was and most probably still is provided for the African majority in South Africa due to a lack of resources, properly qualified teachers and lack of school infrastructure (Fedderke, Kadt and Luiz; 2000). Brand (2004:35) adds that the privilege of education through the medium of the mother tongue is still reserved exclusively for the Afrikaans and English speakers. In summation the Global Entrepreneurial Monitor also 
found that only $13.8 \%$ of South African entrepreneurs had any type of training before starting a business (Bosma, Acs, Autio, Coduras \& Levie; 2009:46).

- $\quad$ African entrepreneurs are younger than Afrikaans and English entrepreneurs - the average ages of all three groups range from 38 to 44 years (see Appendix, Table 5). These findings support research done by Bhola et al. (2006:6), and Reynolds, Bygrave, Autio, Cox and Hay (2002), who found that people between the age of 25 and 44 are most likely to be involved in entrepreneurial activity. According to Bosma et al. (2009:26), the 25 to 34 years age group is the most common age for people to become economically active. Aldrich (1999) found that age is strongly and positively correlated with work experience and fosters the development of entrepreneurial skills.

- A higher proportion of Afrikaans- and English-speaking entrepreneurs had family businesses than the African category (see Appendix, Table 4). According to Bank (1994), few African family businesses existed before 1994 and the current findings suggest that the number of African family businesses is increasing, but has not reached the number of the English and Afrikaans groups.

- $\quad$ English-speaking entrepreneurs are the group with the largest proportion of formal premises, while African entrepreneurs have the largest proportion of businesses that are run from road stalls (see Appendix, Table 4). These findings support research done by Statistics South Africa. The latter estimate that, in 2001, approximately 2.3 million people were owners of at least one small or micro-business (Lehohla, 2002). The vast majority (89.4\%) of these business owners were African. More than two-thirds (67.2\%) were operating these businesses from a dwelling or its surrounding property, and $15 \%$ did not have a fixed site from which to operate the business.

- The majority of Afrikaans and English festival entrepreneurs started their businesses earlier (1997 to 1998) than their African counterparts, who started their businesses in 2000 to 2001 (see Appendix, Table 5).

- The perceived role of entrepreneurs at arts festivals is the same across all three language groups (see Appendix, Table 3). The most important role is product promotion, followed by income generation and festival promotion. This supports research done by Jonker et al. (2009), who indicated that the combination and importance of entrepreneurial attributes seem to be industry or sector specific.

\section{LIMITATION OF THE STUDY}

The greatest limitation of this study was the absence of more black festival entrepreneurs at these festivals. 


\section{IMPLICATIONS}

Based on the results of the research, three main implications were identified:

- Firstly, these results shed light on the differences among festival entrepreneurs and confirm that differences do exist, as was indicated in the findings above. These findings therefore enable government agencies at all levels of government who are involved in funding and promotion of entrepreneurial development as well as festival organisers to increase the number of festival entrepreneurs. The reason is that festival entrepreneurs play a vital role in the future of arts festivals, since they attract, entertain and sell products and services to visitors as well as create job opportunities. The above could be achieved by means of creating opportunities for potential festival entrepreneurs to become part of a particular festival by giving discount to first-time entrepreneurs at a festival, and/or giving preference to festival entrepreneurs who are entering with new or more innovative products. A special prize or award with the aim of assisting newcomers could also be awarded annually to the most innovative new products/services at the festival.

- Secondly, festival organisers should be more actively involved in accommodating festival entrepreneurs, especially from the African language groups. This could be done by hosting workshops for potential festival entrepreneurs as well as developing a more proactive communication strategy that covers a wider range of media in order to inform potential black entrepreneurs. Added to this the latter require more training and government agencies should assist in this regard. Festival entrepreneurs might require training in aspects such as determining price, ensuring quality and authentic products, how to conduct business and how to market and sell products effectively.

- Thirdly, since most black entrepreneurs run their businesses from informal dwellings, assistance by government agencies and festival organisers is required to ensure greater sustainability. This could be achieved for example by subsidising new entrants.

\section{DIRECTIONS FOR FUTURE RESEARCH}

Based on the results of this research, it is recommended that a similar study should focus more on an analysis of African festival entrepreneurs at other festivals in order to obtain more insight into the socio-demographics of the different African language groups. It would also be useful to determine the types of training that festival 
entrepreneurs require. Lastly research should also be conducted on the relationship between festival entrepreneurs and other stakeholders.

\section{CONCLUSIONS}

The purpose of this research was to identify the socio-demographic differences of festival entrepreneurs at two national arts festivals in South Africa. The literature review could not confirm that similar research has been conducted at national arts festivals, which is an indication that this is an area where more research is required. The reason is that the number of events and specifically festivals is constantly increasing in South Africa. Hence growth in this sector creates more opportunities for festival entrepreneurs both current and potential. Results indicated significant differences between the different language groups (Afrikaans, English and African languages). This implies that a different approach is required if one wants to see growth in specifically the number of black festival entrepreneurs. Also, the latter require greater assistance in terms of training, being informed about festivals and a venue from where they can operate their businesses on a daily basis. These differences could also be an indication of different needs. However, an interesting finding was in terms of the role and function of festival entrepreneurs which indicated no differences. This shows that in terms of the core business the different language groups are in accord.

\section{REFERENCES}

ADAM, H. \& MOODLEY, K. 1993. The negotiated revolution. Johannesburg: Jonathan Ball.

AHWIRENG-OBENG, F. 2005. Internationalising South African entrepreneurship: Identifying strategy drivers for competitive superiority. Africa Insight, 35(3): 13-18. Available: SAePublications.

AGGESTAM, M. 2007. Art-entrepreneurship in the Scandinavian music industry. (In Henry, C. Entrepreneurship in the creative industries: An international perspective. Cheltenham, UK: Edgard Elgar. pp. 30-53).

ALDRICH, H.E. 1999. Organizations evolving, London: Sage.

ALLEN, J., O'TOOLE, W., HARRIS, R. \& MCDONNELL, I. 2008. Festival \& special event management. $4^{\text {th }}$ edition. Australia: Wiley. $637 \mathrm{p}$. 
AMOATENG, A.Y. \& RICHTER, L.M. 2007. Social and economic context of families and households in South Africa. (In Amoateng, A.Y. \& Heaton, T.B. eds. Families and households in post-apartheid South Africa: Socio-demographic perspectives. Cape Town: HSRC Press. p. 1-25.).

AUDRETSCH, D.B. \& THURIK, A.R. 2001. What is new about the new economy: sources of growth in the managed and entrepreneurial economies. Industrial and Corporate Change, 10(1): 25-48.

BANK, L. 1994. Between traders and tribalists: Implosion and the politics of disjuncture in a South African homeland, African Affairs, 93(370):75-99.

BERGER, B. 1991. Introduction in the culture of entrepreneurship. San Francisco: Institute for Contemporary Studies.

BHOLA, R., VERHEUL, I., THURIK, R. \& GRILO, I. 2006. Explaining engagement levels of opportunity and necessity entrepreneurs. EIM Business and Policy Research, 1-45.

BOLTON, B. \& THOMPSON, J. 2004. Entrepreneur: Talent, Temperament, Technique. $2^{\text {nd }}$ edition Oxford: Elsevier. 415p.

BOSMA, N., ACS, Z.J., AUTIO, E., CODURAS, A \& LEVIE, J. 2009. Global Entrepreneurship Monitor: 2008 Executive report. GEM Global Entrepreneurship monitor. London: London Business School

BRAND, G.V.W. 2004. 'English only'? Creating linguistic space for African indigenous knowledge systems in higher education. South African Journal of Higher Education. 18(3): 27-39.

BYGRAVE, W. \& MINNITI, M. 2000. The social dynamics of entrepreneurship. Entrepreneurship Theory and Practice. 24(3): 25-36.

CARREE, M.A. \& THURIK, A.R. 2003. The impact of entrepreneurship on economic growth. (In Audretsch, D.B. \& Acs, Z.J., eds., Handbook of Entrepreneurship Research, Boston/Dordrecht: Kluwer Academic Publishers, 437-471.)

CO, M.J. 2003. A socio-cultural explanation of black entrepreneurship in South Africa. South African Journal of Business Management, 34(4):35-44. 
DE HAAS, M. 1990. Ethnicity in perspective. Democracy in Action, Feb.

DUENING, T.N. \& SHERRILL, W.W. 2007. Entrepreneurism: Exploring entrepreneurship from a business process perspective. USA: Thomson. 336p.

FEDDERKE, J.W., KADT, R.D. \& LUIZ, J.M. 2000. Uneducation South Africa: The failure to address the 1910-1993 legacy. International Review of Education. 46(3/4): 257-281.

GARTNER, W.B. 1990. What are we talking about when we talk about entrepreneurship? Journal of Business Venturing, 5: 15-28.

GETZ, D. 2007. Progress in Tourism Management: Event tourism: Definition, evolution, and research. Tourism Management, 29(2008): 403-428.

GODSELL, G. 1991. Entrepreneurs embattled: Barriers to entrepreneurship in South Africa. (In B. Berger The culture of entrepreneurship. California: ICS Press. 85-98)

HAYTON, J.C., GEORGE, G. \& ZAHRA, S.A. 2002. National culture and entrepreneurship: A review of behavioural research. Entrepreneurship Theory and Practice. 33-52.

HOFSTEDE, G., NOORDERHAVEN, N.G., THURIK, A.R., UHLANER, L.M., WENNEKERS, A.R.M \& WILDEMAN, R.E. 2004. Culture's role in entrepreneurship: self-employment out of dissatisfaction. (In Brown, T.E. \& Ulign, J., eds. Innovation, entrepreneurship and culture: The interaction between technology, progress and economic growth. Cheltenham, UK: Edgard Elgar. p. 162-203).

JACKSON, M.J. \& O'SULLIVAN, D. 2002. Festival tourism: A contributor to sustainable local economic development? Journal of Sustainable Tourism, 10(4): 325-342.

JONKER, E., SAAYMAN, M. \& DE KLERK, S. 2009. The role and attributes of entrepreneurs at the Klein Karoo National Arts (KKNK) Festival. Journal of Tourism and Cultural Heritage, 7(3):381-392.

KALULE-SABITI, I., PALAMULENI, M., MAKIWANE, M. \& AMOATENG, A.Y. 2007. Family formation and dissolution patterns. (In Amoateng, A.Y. \& Heaton, T.B. eds. 
Families and households in post-apartheid South Africa: Socio-demographic perspectives. Cape Town: HSRC Press. p. 89-112.)

KITSHOFF, H. 2004a. Klein Karoo Nasionale Kunstefees (KKNK) - Oudtshoorn, 311 April 2004. South African Tourism Journal, 18:237-241. Available: SAePublications.

KITSHOFF, H. 2004b. Grahamstown National Arts Festival - Grahamstown, 1-10 July 2004. South African Tourism Journal, 18:246-249.

LEHOHLA, P. 2002. The contribution of small and micro enterprises to the economy of the country: A survey of non-VAT-registered businesses in South Africa Part 2 Narrative report. Pretoria: Statistics South Africa 56p.

LIGTHELM, A. 2006. An evaluation of the role and potential of the informal economy for employment creation in South Africa. South African Journal of Labour Relations, 30(1): 30-50.

MESTHRIE, R. 2008. South Africa: The rocky road to nation building. (In Simpson, A. Language and national identity in Africa. New York: Oxford University Press. p. 316-338).

MULLER, C.F.J. 1980. Inleiding. (In Muller, C.F.J. 500 Jaar Suid-Afrikaanse geskiedenis. $3^{\text {rd }}$ edition Pretoria: Academica. p. ix-xi).

PISSOORT, V. \& SAAYMAN, M. 2007. Market segmentation of visitors at three selected arts festivals in South Africa. Acta Commercii. 255-268.

REYNOLDS, P.D., BYGRAVE, W.D., AUTIO, E., COX, L.W. \& HAY, M. 2002. Global Entrepreneurship Monitor, 2002 Executive Report. London: London Business School SAAYMAN, M., DOUGLAS, M. \& DE KLERK, S. 2009. Attributes of entrepreneurs at an arts festival. Southern African Journal of Entrepreneurs and Small Business Management, 2(1):17-29

SAAYMAN, M. \& KRUGER, M. 2008. Travel motives of visitors attending Oppikoppi Music Festival. Acta Academica, 41(4):56-73

SENIK, C. \& VERDIER, T. 2008. Entrepreneurs, social networks and work values of ethnic minorities in France. International Journal of Manpower, 29(7): 610-629.

SHEN, J. \& SAIJO, T. 2007. Re-examining the relations between sociodemographic characteristics and individual environmental concern: Evidence from Shanghai data. Journal of Environmental Psychology, 28: 42-50. 
SLABBERT, E., SAAYMAN, M., SAAYMAN, A. \& VIVIERS, P. 2007a. Sosioekonomiese impak van besoekers aan die ABSA KKNK 2007. Potchefstroom: Institute for Tourism and Leisure Studies.

SLABBERT, E., SAAYMAN, M., SAAYMAN, A. \& VIVIERS, P. 2007b. Socioeconomic impact of visitors to the Grahamstown National Arts Festival 2007. Potchefstroom: Institute for Tourism and Leisure Studies.

SPSS Inc. (2007) SPSS $₫ 16.0$ for Windows, Release 16.0.0, Copyright $\odot$ by SPSS Inc., Chicago, Illinois. www.spss.com

STRYDOM, H. 2003. Mapping the road to multilingualism in South Africa. Acta Academica Supplementum, (2):15-31.

SOUTH AFRICA. 1950. The Population Registration Act , Act No 30 of 1950. Government Printer

TIMMONS, J.A. \& SPINELLI, S. 2004. New venture creation: Entrepreneurship for the $21^{\text {st }}$ century. $6^{\text {th }}$ edition. New York: Irwin. 700p.

THRANE, C. 2008. Earnings differentiation in the tourism industry: Gender, human capital and socio-demographic effects. Tourism Management, 29: 514-524.

TUSTIN, D.H., LIGHTHELM, A.A., MARTINS, J.H. \& VAN WYK, H.J. 2005. Marketing Research in Practice. Pretoria: UNISA Press. 749p.

ULIGN, J. \& BROWN, T.E. 2004. Innovation, entrepreneurship and culture, a matter of interaction between technology, progress and economic growth? An introduction. (In Brown, T.E. \& Ulign, J., eds. Innovation, entrepreneurship and culture: The interaction between technology, progress and economic growth. Cheltenham, UK: Edgard Elgar. p. 1-38).

VAN STEL, A.J., CARREE, M.A. \& THURIK, A.R. 2005. The effect of entrepreneurial activity on national economic growth. Small Business Economics, 24(3): 311-321.

WHITFORD, M. 2004a. Regional development through domestic and tourist event policies: Gold Coast and Brisbane, 1974-2003, UNLV Journal of Hospitality, Tourism and Leisure Science, 1: 1-24.

WHITFORD, M. 2004b. Event public policy development in the Northern SubRegional Organisation of Councils, Queensland Australia: Rhetoric or realisation? Journal of Convention and Event Tourism, 6(3): 81-99. 
